ISSN: 1641-4713; e-ISSN: 2081-1160

DOI: https://doi.org/10.36551/2081-1160.2021.27.7-29

\title{
"Uma história difícil de ser contada": A experiência do deslocamento forçado e os dilemas da memória e do esquecimento
}

\author{
"A history hard to be told": The experience of forced displacement \\ and the dilemmas of memory and forgetting
}

Roseli Boschilia

Universidade Federal do Paraná, Brasil

ORCID iD: https://orcid.org/0000-0003-1743-9338

E-mail: roseli.boschilia@gmail.com

Recepción: 7.12.2020

Aprobación: 28.06.2021

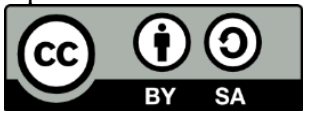

Resumo: Este texto tem como objetivo refletir sobre os dilemas da memória e do esquecimento presentes em relatos de sujeitos históricos que vivenciaram a experiência do deslocamento forçado. Para tanto, recorremos às narrativas de Boleslawa Smolinska Kowalczuk, imigrante de origem polonesa, que se radicou no Brasil na segunda metade da década de 1940 e cuja trajetória pessoal foi marcada, de modo irreversível, pela experiência do recrutamento compulsório, no contexto da Segunda Guerra Mundial. O registro de sua história de vida resultou de uma longa entrevista realizada em 2006, no âmbito de um projeto que teve como principal objetivo a coleta de relatos de história de vida de imigrantes europeus que, no período pós-guerra, escolheram o Brasil como país de destino. A partir do diálogo com autores que contribuem para as discussões epistemológicas em torno da experiência do deslocamento forçado e dos conceitos de memória e identidade, a entrevista de Boleslawa está aqui sendo analisada como uma fonte histórica capaz de fornecer elementos para refletir sobre a potencialidade das narrativas autobiográficas no exercício de reconstrução do passado, processo esse que é mediado pela relação interativa e inseparável com o tempo presente, no interior de um movimento dialético entre a história e a memória, a lembrança e o esquecimento, o silêncio e a narratividade, o dito e o sentido.

Palavras-chave: Segunda Guerra Mundial, imigrantes poloneses, deslocamentos forçados, recordações traumáticas, memória e esquecimento. 


\begin{abstract}
This text aims to reflect on the dilemmas of memory and forgetfulness present in reports by historical subjects who experienced the experience of forced displacement. For that, we resort to the narratives of an immigrant of Polish origin, whose personal trajectory was irreversibly marked by the experience of compulsory recruitment, in the context of the Second World War. The recording of her life story resulted from a long interview conducted from the methodology of oral history, in which she provides important elements to reflect on the potential of autobiographical narratives in the exercise of reconstructing the past, whose images and representations emerge, always mediated for the interactive and inseparable relationship with the present time, in the dialectical movement between history and memory, remembrance and forgetfulness, silence and narrativity, saying and meaning.
\end{abstract}

Palavras clave: Second World War, Polish immigrants, forced displacements, traumatic memories, remembering and forgetting.

INTRODUÇÃO

$\mathrm{O}$ cronista que se põe a contar os acontecimentos sem distinguir pequenos e grandes presta tributo à verdade de que nada do que alguma vez tenha acontecido pode ser considerado perdido para a história. (Benjamin, 1985, p. 155)

Sentada na sala de estar da sua casa em Curitiba ${ }^{1}$, cidade na qual reside desde que chegou no Brasil, em 1947, Boleslawa Smolinska Kowalczuk, deu início à narrativa sobre sua história de sua vida ${ }^{2}$, com a seguinte advertência: "Olha, a minha vida é muito, muito dificil de escrever [...]". Esta frase, proferida com forte carga testemunhal, nos oferece subsídios para a reflexão sobre o papel ativo e produtor dos sujeitos históricos no processo de reconstrução de suas lembranças e, por essa razão, pode ser apropriada como elemento chave para problematizar questões associadas às memórias traumáticas. Como sabemos, é comum que pessoas que vivenciaram a experiência da Guerra encontrem barreiras para narrar eventos dolorosos dos quais elas participaram direta ou indiretamente e, por esse motivo, preferem manter encapsuladas recordações que possam provocar sofrimento ou desconforto (Pollak, 1989, p. 8). A dificuldade de falar sobre eventos traumáticos, reprimidos ou negados, como adverte Jelin (2002, p. 5), pode ocasionar um colapso no processo de compreensão, provocando lacunas que impedem a capacidade de explicar o ocorrido. Corroborando essa ideia, Seligmann-Silva

\footnotetext{
${ }^{1}$ Cidade localizada no sul do Brasil, capital do estado do Paraná. O Paraná é o estado brasileiro que abriga o maior número de imigrantes poloneses.

${ }^{2}$ Entrevista realizada pelas historiadoras Etelvina Maria de Castro Trindade e Roseli Boschilia, em junho de 2006. A gravação, bem como o documento transcrito da entrevista, realizada a partir da metodologia da história oral, estão depositados no acervo do Centro de Referência Documental, da Universidade Tuiuti do Paraná.
} 
(2005, p. 79) também defende que "a impossibilidade da narração advém do excesso de realidade com o qual os sobreviventes haviam se defrontado". Estes argumentos podem ser utilizados para justificar a baliza temporal alargada entre a experiência vivida nos campos de concentração e os textos autobiográficos de autores como Primo Levi, Ruth Kugler e Eli Wiesel, nos quais memórias que durante décadas ficaram confinadas ao silêncio, rompem as barreiras do indizível, estabelecendo um doloroso diálogo com o passado despótico.

No caso da nossa entrevistada, convém lembrar que, ainda que ela não tenha passado pela experiência do confinamento em campos de concentração, a sua experiência não foi menos dolorosa do que a de tantas outras vítimas da Segunda Guerra Mundial. O fato de ter sido recrutada pelas forças nazistas, aos 14 anos de idade, para trabalhar na Alemanha e só ter retornado ao seu lugar de origem quando já tinha cinquenta anos, deixou marcas irredutíveis em sua memória. Desse modo, segundo ela, relembrar a experiência do deslocamento forçado, bem como os desdobramentos provocados pela guerra na sua trajetória de vida, "sempre foi um sofrimento grande demais" (B. S. Kowalczuk, comunicação pessoal, 8 de junho, 2006).

O rompimento da barreira, imposta pelas feridas que as recordações do passado lhe causavam, ocorreu graças à insistência de algumas pessoas ligadas ao seu restrito círculo de amizades, com quem ela, eventualmente, partilhava suas lembranças. E, foi justamente a partir da intermediação de um desses indivíduos, que Boleslawa se dispôs a compartilhar conosco a sua história de vida ${ }^{3}$. Mas, para além do estímulo recebido dos amigos, vale destacar um outro fator que certamente contribuiu para que aquela "história difícil de ser contada" fosse narrada: a clara percepção que ela tinha, na época da entrevista, acerca da finitude do seu tempo de vida. Um terceiro elemento que também merece ser apontado no processo que culminou na realização desta entrevista, está relacionado ao fato de que, como ressalta Pollak (1989, p. 6), para que uma pessoa se interesse em relatar seus sofrimentos, é necessário, antes de mais nada, que ela encontre uma escuta.

Destarte, quando o nosso diálogo teve início, as recordações de Boleslawa, que por mais de meio século haviam ficado restritas à esfera familiar, foram narradas como se ela pudesse, enfim, revisitar lugares, acontecimentos e pers-

\footnotetext{
${ }^{3}$ Cabe esclarecer que a metodologia de história oral adotada durante esta entrevista seguiu o modelo conhecido como história de vida, no qual a narradora longe de seguir um roteiro imposto pelas entrevistadoras, teve total liberdade para abordar assuntos relacionados à sua experiência de vida sobre os quais ela desejava falar. Às entrevistadoras, nesse caso, coube o papel de ouvintes que se manifestaram apenas com o objetivo de esclarecer aspectos que, porventura, não tenham ficado suficientemente claros ao longo da narrativa.
} 
onagens, cujas imagens iam lentamente emergindo dos escombros da memória, como fantasmas que jamais a abandonaram.

Investida do seu papel de narradora, a entrevistada principiou seu testemunho, fornecendo elementos sobre sua identidade e seu lugar de origem:

Meu nome é Boleslawa, mas todo mundo só me chama de Bolka [...]. Eu nasci lá no norte da Polônia, no ano de 1926. Kędziorowo 4 é o nome do lugar onde eu nasci. Fica a duzentos e poucos quilômetros de Varsóvia, lá no Norte. Uma aldeia, sabe [...]. (B. S. Kowalczuk, comunicação pessoal, 8 de junho, 2006) ${ }^{5}$

Após referir estas informações iniciais e pedir desculpas pela dificuldade com a língua portuguesa, Bolka passou imediatamente a compartilhar recordações relacionadas ao contexto histórico da Segunda Guerra Mundial. No relato sobre as marcas deixadas por aquele conflito no território europeu, destacou o genocídio de seis milhões de pessoas, bem como a destruição causada pelos bombardeios, fome e doenças. Porém, à medida que sua narrativa convergia para fatos associados à história da sua família, a emergência daquele conflito e seus desdobramentos ganharam contornos ainda mais trágicos, tendo em vista as marcas irreversíveis que a guerra deixou na sua experiência vivida ${ }^{6}$.

Assim, no exercício de revisitar o passado, Bolka, olhando através da janela, como se buscasse forças para recuperar cenas obliteradas pela ação corrosiva do tempo, passou a discorrer sobre o cotidiano da sua família no período que antecedeu a Segunda Guerra:

Meu pai era agricultor, não é dos grande, mas também médio, sabe. Nós era uma família, muito, muito unida, com muito amor de verdade [...]. Mas em 39 veio a guerra, depois veio os russos [...]. Eu tinha uma irmã mais velha e um irmão, três anos mais novo, que ainda tá vivo [...]. Minha irmã morreu de tifo ... foi-se com 18 anos [...]. Muita gente morreu de tifo durante a guerra. (B. S. Kowalczuk, comunicação pessoal, 8 de junho, 2006)

Nas entrelinhas de sua narrativa, é possível perceber que, embora tenha deixado de mencionar o fator crucial para o início da guerra, que foi a invasão da Polônia pela Alemanha, e tampouco tenha feito referência à divisão do território polonês, entre a Alemanha e a União Soviética, Bolka demarcou claramente estes dois momentos ao afirmar que "veio guerra em 39, depois veio os russos". Ou

\footnotetext{
${ }^{4}$ Vila localizada na região nordeste da Polônia, na província de Podlaskie, condado de Grajewo.

${ }^{5}$ Com o objetivo de respeitar o estilo linguístico da narradora, elemento importante para acompanhar a organização de sua construção narrativa, optou-se pela transcrição literal da entrevista, sem interferências ou correções no que tange às regras gramaticais.

${ }^{6}$ Ricoeur, apoiado em Koselleck (1979) afirma que "por espaço de experiência é preciso entender as heranças, os traços sedimentados do passado, constitutivos do solo em que assentam desejos, temores, previsões, projetos, antecipações, que se destacam do fundo do horizonte de espera" (Ricoeur, 1995, p. 2).
} 
seja, ainda que desconhecesse as questões geopolíticas que estavam por trás das negociações e dos conflitos entre a Alemanha e a União Soviética, ela sabia, a partir da história vivida "na própria carne", que a Polônia havia sido ocupada por forças nazistas e soviéticas.

$\mathrm{Na}$ sequência do nosso diálogo, quando foi motivada a discorrer sobre a sua trajetória escolar, Bolka, depois de refletir por alguns instantes, recordou:

Escola, escola. Veja só, como a escola da nossa aldeia queimou, então como meu pai tinha uma salona grande, então ele alugou essa salona como se fosse para escola... mas depois estava outra casa também [...] até o quarto ano, tinha na aldeia. Do quarto ano em diante tinha que ir cinco quilômetros, e eu andava, sabe [...]. (B. S. Kowalczuk, comunicação pessoal, 8 de junho, 2006)

Assim, a partir de sua construção narrativa, ela procurou introduzir gradativamente suas interlocutoras no universo de sua infância e adolescência, vividas no contexto histórico da chamada Segunda República Polonesa, que vigorou entre 1918 e 1939. No curto espaço de tempo em que Bolka residiu em sua terra natal, vale lembrar, que a principal liderança política da Polônia era o marechal Józef Piłsudski, visto como responsável pela conquista da independência do país, no final da Primeira Guerra Mundial. Em 1926, no mesmo ano em que Bolka nasceu, Piłsudski, com o apoio de um grupo político denominado Sanacja (Saneamento), promoveu um golpe de estado, instaurando um governo autoritário que se estendeu até $1939 .^{7}$

Contudo, Bolka, além de não fazer qualquer referência à figura daquele governante, mencionou apenas alguns aspectos relacionados ao contexto político da Segunda República Polonesa, especialmente aqueles que diziam respeito à precariedade do ensino, tendo em vista a inexistência de escolas de segundo ciclo na sua aldeia.

Embora a narradora não faça referência ao contexto social no qual a sua família estava inserida, é possível perceber, a partir de diversos fragmentos da sua narrativa, que sua família pertencia a um estrato social distinto da população mais pobre. Isto porque seus pais, além de serem proprietários de alguns hectares de terra, possuíam algumas cabeças de gado e os filhos tinham acesso à escolaridade. Outro vestígio presente em seu relato é de que a sua família residia em uma casa relativamente ampla, em condições de abrigar, mesmo que provisoriamente a escola da comunidade, que antes da guerra fora destruída por um incêndio.

\footnotetext{
${ }^{7}$ Mesmo após a morte de Piłsudski, ocorrida em 1935, um grupo de coronéis, respaldado por uma nova Constituição de inspiração fascista, conseguiu se manter no poder até setembro de 1939, momento em que a invasão dos soldados nazistas à Polônia deflagrou o conflito que deu origem à Segunda Guerra Mundial.
} 
Desse modo, uma das razões para que Bolka não tenha elencado em sua narrativa aspectos ligados ao cotidiano da sua aldeia no período em que Piłsudski esteve no poder, talvez possa ser atribuída ao fato de que aquele governo não tenha promovido alterações substanciais no modo de vida de sua família, ao contrário do que ocorreu posteriormente, com o advento da Guerra.

No processo de rememoração sobre o cotidiano dos moradores da sua aldeia, a partir do início da Guerra, a questão educacional ressurgiu em sua narrativa como um dos aspectos que mais evidenciaram as mudanças ocorridas naquele contexto. Assim, na continuidade do seu relato, sem deter-se em aspectos ligados aos métodos de ensino ou aos conteúdos das disciplinas que eram ministradas nas instituições escolares, Bolka ressaltou os problemas enfrentados pela sua geração no que tange à imposição cultural que estava associada ao projeto mais amplo de dominação política e militar colocado em prática tanto pelo governo soviético quanto pelo governo nazista. Ao falar sobre a sua inclinação pelos estudos, Bolka recordou, com certa amargura no olhar:

Eu ia muito bem [na escola], ia muito bem na matemática, eu era muito esperta ... mas de 39 até 41, tinha os russos no lugar da Polônia. Então tinha que ir para a escola e tinha que aprender russo ... e quando tava os russos eu não gostava [de estudar]. (B. S. Kowalczuk, comunicação pessoal, 8 de junho, 2006)

Ao ser questionada acerca dos motivos que a levaram a perder o gosto pelos estudos, a narradora manifestou a sua contrariedade em relação à política de dominação cultural que era imposta nas escolas, com o claro objetivo de enfraquecer as raízes identitárias da população polonesa, dizendo:

Porque a gente tinha uma coisa dentro da gente, vamos dizer, a gente tinha que aprender esses hinos comunistas, então a gente olhava se ela [a professora] não tava vendo a gente... [Acompanhar] a melodia ainda, mas as palavras a gente colocava do hino polonês. (B. S. Kowalczuk, comunicação pessoal, 8 de junho, 2006)

Vale lembrar, que, apesar da sua narrativa exemplificar algumas táticas de resistência utilizadas pelos estudantes, com o intuito de se contrapor ao projeto de dominação cultural imposto pelos seus opressores, em outros momentos da entrevista, ela não deixou de mencionar aspectos que colocaram em relevo os obstáculos encontrados pela sociedade polonesa para fazer frente ao violento projeto de erradicação da sua cultura. A repressão à religião católica, o fechamento dos jornais e das escolas foram alguns dos exemplos referidos durante a entrevista ${ }^{8}$.

\footnotetext{
${ }^{8}$ De acordo com Lukas (1986), o número de matrículas nas escolas, durante o Governo Geral sofreu uma redução de 50\% em relação ao período anterior à Segunda Guerra.
} 
“A GENTE NÃO PODIA DIZER NÃO”

Na sequência da narrativa, Bolka passou a discorrer sobre a difícil experiência pela qual ela e milhares de jovens do leste europeu passaram, ao serem recrutados compulsoriamente pelas forças nazistas para substituir os trabalhadores alemães (Shephard, 2012).

Como se sabe, a política de recrutamento de trabalhadores poloneses e ucranianos teve início em 1939, logo após as autoridades de ocupação alemã instaurarem o Governo Geral. A historiografia nos mostra que essa modalidade de trabalho forçado ${ }^{9}$ já havia sido colocada em prática durante a Primeira Guerra, quando a Alemanha apresentou um déficit significativo da sua força laboral, em razão da maior parte dos civis terem se alistado no exército (Shephard, 2012). No início da Segunda Guerra, como este mesmo autor observa, o governo alemão fez uso intensivo de propaganda em jornais, cinemas e até mesmo em cartazes, que eram divulgados nos espaços públicos, com o intuito de atrair mão de obra do leste europeu para atuar no setor agropecuário (Sheppard, 2012, p. 29). Entretanto, a estratégia não surtiu efeito e, por conta disso, as autoridades nazistas decidiram promover alterações na legislação e, desse modo, o recrutamento de trabalhadores estrangeiros passou a ser compulsório (Santos, 2020, p. 28). A nova legislação, que inicialmente atingia os jovens poloneses do gênero masculino, entre 14 e 25 anos, logo depois se estendeu também às mulheres pertencentes a mesma faixa etária.

Uma das práticas adotadas pela polícia nazista para engajar o maior número de trabalhadores do leste europeu, era recrutá-los não só nos espaços urbanos, como mercados e igrejas, mas também em incursões realizadas em bairros e aldeias (Holocaust Museum, s.d.-b). Foi a partir dessa modalidade de abordagem que Bolka e outros jovens da sua faixa etária, foram submetidos ao deslocamento forçado. O comportamento arbitrário da polícia nazista em relação ao recrutamento compulsório também é evidenciado na narrativa de outro imigrante polonês que, tal como Bolka, se radicou no Paraná no período pós-guerra. Ao descrever as condições de vida dos trabalhadores poloneses no contexto da Guerra, o imigrante, Wallace Witkowski, fez o seguinte relato durante uma entrevista concedida à jornalista Polliana Milan:

\footnotetext{
${ }^{9}$ Ainda que essa categoria de trabalhadores, que era recrutada pelos alemães para atuar no setor agrícola ou industrial, não tenha sido aprisionada em campos de concentração, é importante lembrar que essa modalidade de trabalho era realizada de modo coercitivo (Holocaust Museum, s.d.-a).
} 
Fomos, claro, sobreviventes de um período durante o qual qualquer pessoa saudável, com 14 anos ou mais, tinha que trabalhar 10 horas por dia, 6 dias por semana. Caso contrário, éramos enviados para campos de trabalho na Alemanha ou para trabalhar nas fábricas de máquina de guerra alemã. (Milan, 2012)

Para se ter uma ideia do intenso fluxo de trabalhadores recrutados pelas forças nazistas, basta lembrar que nos primeiros meses da década de 1940, saíam diariamente da Polônia, com destino à Alemanha, cerca de dez trens, levando cada um deles, em média, mil trabalhadores (Shephard, 2012).

As estatísticas, embora imprecisas, mostram que durante a Segunda Guerra mais de um milhão de homens e mulheres polonesas foram levados para a Alemanha, sendo que alguns autores chegam a afirmar que no auge do conflito, os poloneses representavam $20 \%$ dessa força de trabalho.

Um aspecto a ser destacado, quando abordamos a questão do deslocamento forçado, diz respeito à distinção que precisa ser feita entre o grupo populacional que foi recrutado coercitivamente para exercer trabalho remunerado, em substituição a mão de obra alemã, e o grupo constituído por judeus e os ciganos que foi submetido ao trabalho forçado nos campos de concentração, em condições muito mais degradantes. ${ }^{10}$ Importante lembrar que os componentes do grupo do qual Bolka fazia parte pertenciam à categoria dos trabalhadores civis. A principal distinção entre os trabalhadores que foram levados para os campos de concentração e os chamados trabalhadores civis é que estes, além de serem remunerados, ficavam alojados na propriedade dos seus empregadores. No entanto, é preciso lembrar que a acomodação na casa dos patrões, longe de significar uma regalia, visava tão somente facilitar o controle e a vigilância sobre os trabalhadores estrangeiros.

\section{“E NEM MÃE, NEM PAI PODIA DIZER NADA"}

Dando continuidade à sua narrativa, com a voz embargada, Bolka procurou destacar o acontecimento que, segundo ela, foi definitivo para a mudança de rumo da sua trajetória de vida. Ao revisitar seus espaços de recordação, retornou ao ano de 1941, reconstruindo sempre com os pés fincados no presente, o cenário no qual ela e irmã foram interceptadas abruptamente por um oficial nazista, no trajeto entre a residência da família e a área destinada ao cultivo agrícola:

\footnotetext{
${ }^{10}$ Aqui, além de destacar novamente os importantes relatos autobiográficos deixados por Primo Levi, Ruth Kugler e Eli Wiesel, não podemos deixar de referir o trabalho de autores como Pollak $(1989,1992,2010)$ e Calegari (2019), que, a partir da metodologia da história oral, se debruçaram sobre narrativas que enfocam o trabalho forçado em campos de concentração.
} 
Depois em 41, veio os alemães [...]. Um dia de manhã cedo eu [e minha irmã] ia colher batata na nossa chácara. Aí veio um alemão, sabe, claro, com um fuzil e disse que uma [das duas] tinha que acompanhar ele porque tem que ir trabalhar na Alemanha. A gente não tinha outra resposta a dizer. Não... isso não existia pra nós [...]. e nem mãe, nem pai podia dizer nada (B. S. Kowalczuk, comunicação pessoal, 8 de junho, 2006)

Ao relembrar o momento em que o agente alemão chegou para recrutar um dos membros da família, ela recordou que, tendo em vista que seu irmão era ainda menor de idade, a escolha recairia obrigatoriamente sobre uma das duas irmãs. E, de acordo com as normas estabelecidas pelo Governo Geral, o recrutamento deveria incidir sobre a filha mais velha. Entretanto, segundo Bolka, ela própria teria persuadido o recrutador a alistá-la no lugar da irmã mais velha, utilizando como argumento o fato de que a mão de obra da filha primogênita era imprescindível para a subsistência da família. Obliterando a presença do policial no diálogo que ela teria travado com a irmã a respeito de quem deveria acompanhá-lo, Bolka nos conta:

Aí eu como era a mais assim... que não, não pensava muito, sabe, digo: ‘Não, você não, porque em casa tem muita coisa pra fazer, tem também muita colheita de batatinha e eu vou... aí eles me mandam de volta, sabe, os alemães, eles me mandam de volta'. Ai foi-se $e u$. (B. S. Kowalczuk, comunicação pessoal, 8 de junho, 2006)

Interessante notar neste fragmento da sua narrativa que, ao invés de falar sobre o sentimento de medo que certamente acometeu as duas irmãs diante do soldado nazista armado de fuzil, Bolka preferiu realizar um exercício de autorrepresentação. Apropriando-se de toda sua "arte de contar" ela atribuiu ao arroubo juvenil, de quem "não pensava muito", o fato de ter assumido o lugar da irmã mais velha, sem levar em conta a gravidade da situação a que ambas estavam sendo submetidas naquele contexto de guerra. Para entender as motivações que teriam levado a narradora a assumir tal postura, é pertinente recorrer às reflexões de Guillaumin e Candau. De acordo com o psicanalista Jean Guillaumin (1968), são as necessidades e desejos presentes do sujeito que podem levá-lo a elaborar uma versão romanceada do passado. Já o antropólogo Jöel Candau defende a hipótese de que, pelo fato do tempo da recordação e do tempo vivido estarem situados em esferas diametralmente distintas, as incertezas inerentes a este poderiam se dissipar naquele e isso justificaria o recurso utilizado por muitos narradores no sentido de procurar embelezar as recordações desagradáveis (Candau, 2013, p. 53). Este autor reforça ainda que, quando rememoradas, as recordações podem ser afetadas pelo "sentimento de tensão provocado pelo caráter incerto da situação vivida em que se receia sempre o pior” (Candau, 2013, p. 53). 
É digno de nota que, depois de rememorar a cena em que assumiu o lugar da irmã, Bolka abandona o discurso autoral e diminuindo o tom de voz, como se temesse ser ouvida, fez questão de esclarecer que naquele contexto não havia nenhuma possibilidade de contestação à ordem policial, pois as pessoas que resistissem ao recrutamento corriam o risco de serem enviadas para um campo de concentração e as famílias podiam sofrer punições. Ao falar sobre o temor das punições que as famílias poderiam sofrer, caso os jovens se recusassem a obedecer às ordens do governo nazista, ela fez questão de mencionar que as notícias relacionadas a casos de punição circulavam, a boca pequena, entre os moradores da sua aldeia, causando muito medo e apreensão. Neste trecho do seu relato, torna-se perceptível o quanto a memória individual de Bolka não deixa de estar ancorada nas narrativas coletivas, pois como observa Ricoeur (1999), as recordações individuais são reforçadas em rituais e comemorações grupais.

De qualquer modo, é curioso perceber na construção do seu relato que, apesar de defender o argumento de que não havia nenhuma possibilidade de se contrapor à ordem policial, teria sido ela a assumir o protagonismo no momento de tomar a decisão sobre qual das duas irmãs seria escolhida para compor a relação de trabalhadores convocados pelo dito oficial nazista. Obviamente, não nos cabe aqui questionar até que ponto a escolha do seu nome coube efetivamente a ela ou se a substituição resultou de uma decisão paterna ou partiu do agente responsável pelo recrutamento. ${ }^{11} \mathrm{O}$ ato de narrar, conforme nos lembra Walter Benjamin, "é uma forma artesanal de comunicação", na qual o narrador deixa impressa sua marca "como a mão do oleiro na argila do vaso" (Benjamin, 1987, p. 205). Nessa perspectiva, longe de confrontar a veracidade dos fatos, o que nos interessa é refletir sobre o modo como Bolka procurou reconstruir sua narrativa, na tentativa de justificar porque a escolha de quem seria recrutada recaiu sobre ela e não sobre a irmã mais velha. Do nosso ponto de vista, o fato da irmã de Bolka ter morrido de tifo poucos meses depois da sua partida para a Alemanha, pode ter contribuído para a sua versão romanceada do passado. Desse modo, corroborando as ponderações de Candau, é possível defender a hipótese de que o tempo da recordação dissipou os temores e as incertezas com as quais ela deve ter se deparado no tempo vivido, dando lugar ao sentimento de afeto que ela dedicava à irmã. Como asseverou Santo Agostinho (2008), a memória encerra os estados afetivos da alma e estes, ao serem evocados, emergem no preciso momento da recordação.

\footnotetext{
${ }^{11}$ De acordo com vários testemunhos, a substituição de trabalhadores convocados para o recrutamento compulsório por outro membro da família, não era algo incomum. Segundo o relato de Ivan Bojko, outro imigrante de origem ucraniano que veio para o Brasil no período pós-guerra, ele foi para a Alemanha no lugar da sua irmã, que havia sido listada na convocação (de Salis, 2020, p. 99).
} 
"E LÁ SE FOI, NESSA FAZENDA, TRÊS ANOS E OITO MESES..."

Após relatar, com certa teatralidade, o episódio que resultou no seu recrutamento, Bolka promove um salto temporal em sua narrativa, mantendo na chamada "zona cinzenta" as lembranças relacionadas aos preparativos para a viagem ou ao deslocamento propriamente dito e passa a falar sobre sua experiência como trabalhadora já em território alemão.

Assim, deixando de convocar personagens ou vozes ligadas ao cenário da sua despedida, Bolka preferiu discorrer sobre aspectos relacionados às dificuldades com as quais se deparou nos primeiros meses em que permaneceu em um alojamento, em condições bastante precárias, antes de seguir para outros dois locais onde trabalhou posteriormente. Neste primeiro local de trabalho, a falta de um lugar para dormir, o frio e a umidade foram algumas questões que mereceram destaque em sua narrativa:

Não foi fácil, porque é ... nós ... quando a gente tem 14 anos pra 15, é tudo isso é ainda inexperiência, não é bem assim. E, foi eu lá na Prússia, como diz lá ... lá fiquei esses dois meses. É difícil, porque a gente não tinha cama pra dormir, dormia numa lavanderia em cima do feno, mas foi ... A gente não tinha roupa porque não deu pra pegar, né, não tinha roupa, não tinha sapato para trocar... a vida tinha que ser assim [...]. Tinha que aceitar sapato molhado no outro dia, sabe, também já tudo ... mas lá se foi. (B. S. Kowalczuk, comunicação pessoal, 8 de junho, 2006)

O relato de que não houve tempo suficiente para pegar roupas e calçados antes de viajar, sugere que os embarques dos trabalhadores eram realizados pelo comando nazista imediatamente após a convocação, certamente para impedir eventuais fugas ou evitar que as famílias se mobilizassem na tentativa de prorrogar a data do embarque.

Assim, frente ao silêncio de Bolka, somos privados de saber quais foram as emoções e sentimentos que a dominaram durante o longo trajeto percorrido para chegar à Alemanha. Tendo em vista o seu estilo eloquente e minucioso nas descrições e nos diálogos, vale a pena perguntar por que razão ela manteve na penumbra episódios relacionados às últimas horas que passou com a família, antes de embarcar para uma viagem, cujo retorno era absolutamente incerto, diante dos rumos que a Guerra estava tomando a partir de 1941, quando o conflito ultrapassou as fronteiras europeias e tornou-se global?

Ao refletir sobre as lacunas existentes na narrativa de Bolka, no que diz respeito especialmente às recordações do momento em que se despediu dos pais, é importante lembrar que as imagens do passado são reconstituídas a partir das marcas afetivas que determinadas experiências deixaram em nós, como afirma 
Paul Ricoeur (citado em Loriga, 2009, p. 20). Assim, o fato de mantermos longe da evocação certas memórias não significa que elas tenham efetivamente se apagado. Como observou Pollak (1989), o silêncio ou a dificuldade de narrar não significam necessariamente esquecimento. Muitas vezes, o silêncio pode ser entendido como sinal de resistência, sobretudo quando a experiência do narrador está atravessada por memórias traumáticas. E nos silêncios de Bolka sobre as experiências indizíveis, talvez se encontre a chave para compreender o porquê dela considerar sua história tão "difícil de ser escrita". Ademais, para que uma história seja escrita, é necessário, antes de mais nada, que ela seja narrada. No momento de selecionar no tempo presente, fragmentos do passado que contribuíram para delinear as dobras de sua subjetividade, talvez tenha sido menos doloroso falar sobre a sua capacidade de reagir e se posicionar diante do oficial nazista, ao "salvar" a irmã do recrutamento forçado, do que reavivar sentimentos de angústia, medo e desamparo e, porque não dizer, de arrependimento, que provavelmente a assolaram no momento em que teve que partir no lugar de sua irmã para enfrentar os desafios impostos pelo deslocamento forçado. Como nos adverte David Lowenthal:

as lembranças não são reflexões prontas do passado, mas reconstruções ecléticas, seletivas, baseadas em ações e percepções posteriores e em códigos que são constantemente alterados, através dos quais delineamos, simbolizamos e classificamos o mundo à nossa volta. (Lowenthal, 1998, p. 103)

\section{“A GENTE NÃO PODIA DIZER NÃO, ESTA PALAVRA ERA PROIBIDA"}

De modo geral, o relato de Bolka acerca da sua trajetória de vida na Alemanha foi atravessado por dois temas em especial: a impossibilidade de retorno à Polônia e as condições de trabalho extremamente adversas.

A expectativa do retorno, que ela alimentou desde o momento em que fora recrutada, ressurgiu em vários momentos da sua narrativa. Ao ser questionada em relação a sua jornada de trabalho na Alemanha, ela respondeu: "Colhi em duas fazendas lá, pra colheita de batatinha. Achava que depois eles mandavam a gente para casa, que nada!” (B. S. Kowalczuk, comunicação pessoal, 8 de junho, 2006).

Ela relata que tão logo encerrou-se a colheita de batatas, foi encaminhada, com um grupo de trabalhadores, para outro estabelecimento agropecuário, situado na fronteira com a Holanda, na região da Baixa Saxônia.

[Depois] mandaram eu perto da fronteira com a Holanda, numa fazenda. Só tinha mais vacas, tinha que tirar muito leite, sabe, porque justamente aconteceu muitos... imprevistos que, olha aí como é meus dedos... pode ver...de tanto tirar leite das vacas com 14 anos, 
$15 . .$. é difícil. Mas tinha que aceitar que não tinha escolha, não tinha mãe para se queixar. Muitas vezes a gente chamava a mãe de noite [choro], mas continuava, né. (B. S. Kowalczuk, comunicação pessoal, 8 de junho, 2006)

O sentimento de desamparo, devido ao fato de estar longe da família, também foi um tema recorrente em sua narrativa. Com o intuito de falar sobre os problemas que precisou enfrentar sozinha, ela fez o seguinte relato:

Agora eu vou contar uma outra coisa pra vocês, vou contar: Veja só, na Polônia o povo era bastante atrasado na aldeia, eu não sabia o que é menstruação, de jeito nenhum [...] ninguém contava. Eu já estava lá na Alemanha, um susto: 'Meu Deus do céu que é isso'. Essas coisas, sabe, como eu digo, infelizmente na época em que eu vivia era assim, sabe.

(B. S. Kowalczuk, comunicação pessoal, 8 de junho, 2006)

Além de relembrar experiências como essa, outra queixa apontada por Bolka foi de que ela não possuía sequer uma fotografia para atenuar as saudades que sentia de casa e de seus pais e irmãos.

Nesse estabelecimento agropecuário situado na região agrícola da Baixa Saxônia, Bolka trabalhou a maior parte do tempo que permaneceu no território alemão, sendo liberada do trabalho forçado somente quando findou a Guerra. Ao descrever o perfil dos trabalhadores que desempenhavam atividades laborais nessa fazenda, ela relembrou:

A dona desta fazenda era uma senhora alemã, ela não era casada, uma fraulein [...]. Nessa fazenda tava uma russa, eu, mais uma polonesa, mas ela só ficou um ano e meio, depois ficou grávida - e grávidas eles mandavam de volta para a Polônia -, um ucraino e um polonês. Quer dizer que nós éramos cinco [pessoas]. Tinha mais um alemão que era gerente, vamos dizer... E lá se foi, nessa fazenda, três anos e oito meses... (B. S. Kowalczuk, comunicação pessoal, 8 de junho, 2006)

Ao narrar a experiência vivida neste período, Bolka procurou chamar a atenção não só para os aspectos ligados à precariedade material, mas, principalmente para as condições de vulnerabilidade as quais os trabalhadores do leste europeu estavam permanentemente expostos:

Eu tinha um quarto no sótão que não era aquecido, os vidros, sabe, foi muito trancado por causa dos bombardeios... porque tinha logo perto a fábrica de munição, sabe. Então sempre tinha os aviões que jogavam suas bombas... e coisas assim [...]. (B. S. Kowalczuk, comunicação pessoal, 8 de junho, 2006)

Como sabemos, a região da Baixa Saxônia foi uma das áreas mais afetadas durante a Segunda Guerra, em razão dos bombardeios promovidos pelas forças aliadas. Relembrando a rotina dos empregados que viviam nesta fazenda, ela observa:

Muitas e muitas noites a gente não podia dormir porque tinha que descer e ficar no bunker, sabe. Isso é a guerra. E no outro dia, ninguém perguntava se você dormiu à noite ou não. Tinha que levantar e fazer todo o serviço que era preciso fazer... E assim se foi três anos 
e oito meses nessa patroa, registrada, tá? Quer dizer que são quatro anos que eu morei

lá [na Alemanha]. (B. S. Kowalczuk, comunicação pessoal, 8 de junho, 2006)

Relata ainda que, alguns meses depois de ter chegado a este último local de trabalho, a expectativa de retorno que ela, ingenuamente, alimentara no período inicial de trabalho forçado, foi substituída pela certeza de que dificilmente teria chances de sair da Alemanha enquanto perdurasse a Guerra. O golpe definitivo para que ela e sua família perdessem por completo a esperança de viabilizar um projeto de retorno, ocorreu pouco tempo depois do falecimento da sua irmã, que foi vitimada pela epidemia de tifo.

Abalados com a morte da filha mais velha, os pais de Bolka tentaram, em vão, trazê-la de volta à Polônia. De acordo com a sua narrativa, uma das táticas utilizadas pelas famílias camponesas com maior poder aquisitivo, para liberar seus filhos do trabalho forçado, era conseguir que outra pessoa, com faixa etária e condição de saúde equivalente, aceitasse ocupar o lugar daquela que havia sido recrutada inicialmente. Na esperança de conseguir seu intento, os pais de Bolka foram em busca de uma família que concordasse com essa troca, conforme ela relata:

Eles pagaram caro prá uma família que mandasse uma outra menina, mais de idade que eu, deram uma vaca com leite e tudo, para ela [vir trabalhar no meu lugar]... pra eu poder voltar para a Polônia, porque tinham perdido uma filha e outra estava longe, sabe... Mas a minha patroa dizia: 'Não adianta medir o bolso dos teus pais com o meu... e acabou'. (B. S. Kowalczuk, comunicação pessoal, 8 de junho, 2006)

O que chama a atenção na narrativa de Bolka é que, embora os trabalhadores recrutados pelo exército alemão assinassem um contrato de trabalho, a relação estabelecida com os empregadores estava muito próxima a de um trabalho análogo ao escravo. Além de estarem submetidos a longas e exaustivas jornadas de trabalho, os empregados também tinham que se subjugar à autoridade inquestionável dos empregadores. Destarte, apesar do esforço empreendido pelos pais de Bolka para levá-la de volta, a decisão de não aceitar a proposta de substituição da mão de obra coube exclusivamente à proprietária da fazenda.

Outro aspecto que Bolka ressalta em sua narrativa diz respeito ao cerceamento da liberdade imposto pelo regime nazista aos trabalhadores do leste, pois estes somente poderiam sair de seus locais de trabalho se estivessem portando as insígnias de diferenciação ${ }^{12}$ e com autorização expressa dos patrões. Ao falar sobre essas práticas de violência, Bolka desabafa:

\footnotetext{
${ }^{12}$ Como observa Shephard (2012), os poloneses receberam a letra P e os ucranianos a expressão ost, abreviação de Ostarbeiter, terminologia que se referia aos trabalhadores do leste europeu.
} 
Vocês imaginem a gente não podia sair de uma chácara pra outra, tinha que ter licença e, ainda sim, a gente tinha que sempre ter um paninho assim com $\mathrm{P}$, de polonês, né, anotado. (B. S. Kowalczuk, comunicação pessoal, 8 de junho, 2006)

Este fragmento da narrativa de Bolka, nos remete às reflexões de Varikas, sobre as "barreiras invisíveis [que] relegam o pária a uma inferioridade social de fato" (Varikas, 2014, p. 112), pois para além do rígido controle que sofriam por parte dos patrões, os trabalhadores também eram vítimas da população em geral, conforme Bolka observa: "E se a gente, vamos dizer, de noite queria sair visitar os outros [...] os velhotes alemães que não foram pro exército [...] batiam na gente, sabe, não tinha jeito" (B. S. Kowalczuk, comunicação pessoal, 8 de junho, 2006) ${ }^{13}$.

Além das práticas de violência promovidas pelos homens mais velhos da comunidade, Bolka chama a atenção para o tratamento segregacionista e xenofóbico que a sociedade alemã, em geral, tinha em relação aos trabalhadores do leste europeu:

Vocês não têm ideia como é que um, assim, polonês ... ucraino não, ucraino já era mais ... mas o russo, polonês, judeu ainda pior, sabe, tem que viver, tem que viver, tem que obedecer cegamente, não... e a gente não podia dizer não, sabe, esta palavra era proibida. (B. S. Kowalczuk, comunicação pessoal, 8 de junho, 2006)

Esta construção narrativa de Bolka, remete novamente às reflexões de Varikas sobre a condição do pária, ao afirmar que este termo, para além de estar diretamente associado “à escravidão, à subjugação, à ideia de uma situação objetiva - um sistema de exploração econômica e exclusão política [...] contém ainda uma forte carga de subjetividade e intersubjetividade ligadas às percepções que a sociedade tem dele" (Varikas, 2014, p. 51).

\section{"E CHEGOU O FIM DA GUERRA, GRAÇAS A DEUS"}

A construção narrativa de Bolka sobre o período em que esteve submetida ao trabalho forçado é recheada de considerações que colocam à mostra os sentimentos e ressentimentos que aquela experiência deixou na sua memória.

E assim se foi, sabe, essa vida de três anos e oito meses, é um bocado de tempo, sabe... Nunca, como diz, nunca tinha um livro, nunca fui numa igreja... [choro]. Não tinha jornal, não tinha rádio, não podia escutar [rádio] mas Deus me ajudou, chegou o fim da guerra, graças a Deus, sabe. (B. S. Kowalczuk, comunicação pessoal, 8 de junho, 2006)

\footnotetext{
${ }^{13}$ A narradora esclareceu que somente com a permissão de seus empregadores os trabalhadores do Leste podiam deixar seus locais de trabalho e que no período final da guerra, a patroa permitia, eventualmente, que eles conversassem com os vizinhos. Nesse sentido, o historiador argentino Osvaldo Coggiola (2015, p. 76), chama atenção para o fato de que com o avanço da guerra e a demanda crescente por mão de obra, o trabalhador do Leste, gradativamente, deixou de ser visto como desprezado (Untermensch), passando a ser considerado como 'trabalhador hóspede'.
} 
Após mencionar as restrições que eram impostas aos trabalhadores do leste, que além de serem proibidos de ouvir rádio ou ler jornais, tampouco tinham o direito de praticar sua religiosidade publicamente, Bolka manifesta seu alívio ao saber que a Guerra tinha chegado ao fim.

Ou seja, a derrota dos países do Eixo, para além de interromper o ciclo de uma experiência traumática, devolvia a ela, bem como as demais pessoas na mesma condição, a tão sonhada liberdade de ir e vir, sem a interferência dos antigos patrões ou de qualquer outra pessoa que tivesse vínculos com o governo nazista.

Entretanto, ao rememorar as cenas do período pós-guerra, Bolka, curiosamente, adota um discurso no qual alguns aspectos que anteriormente colocavam patrões e empregados em campos diametralmente opostos agora passam a ser relativizados.

Terminou a guerra não foi fácil é... sabe não foi fácil pra ninguém, até pros alemães também. Justamente na fazenda onde que eu tava, tinha, que já chegou, sabe, vinha a capitulação, sabe, a gente via aquele desespero deles... e, vamos dizer, a patroa sempre, ela tinha uma, uma coisa assim, acho que ela gostava um pouquinho de mim, porque ela não tinha filho, não tinha nada, mas ela não podia mostrar isso. (B. S. Kowalczuk, comunicação pessoal, 8 de junho, 2006)

Qual a justificativa para que Bolka tenha elaborado no tempo presente, um discurso no qual manifesta seu sentimento de compaixão não só no que diz respeito à figura da antiga patroa, mas também em relação a outras pessoas de nacionalidade alemã? Embora possa parecer paradoxal, a narradora deixa entrever que, apesar de ter vivido em um ambiente marcado pela aparente ausência de laços afetivos, Bolka acabou depositando na figura autoritária da patroa o lugar que anteriormente cabia aos seus pais, no universo dos afetos.

A brusca inversão que a Guerra provocou nas relações de poder entre patrões e empregados, colocando os últimos numa condição privilegiada, teria levado Bolka a revisar os seus sentimentos em relação as pessoas que estiveram a sua volta, ao longo de quatro anos de convivência. Um certo ar de superioridade em relação àqueles que anteriormente ocupavam o lugar de algozes pode ser vislumbrado no trecho em que ela, com uma ponta de orgulho, destaca o fato de terem sido os soldados poloneses os responsáveis pela libertação do território onde ela se encontrava ${ }^{14}$.

${ }^{14}$ Conforme evidenciado pela historiografia, durante a Segunda Guerra Mundial a $1^{\text {a }}$ divisão de Blindados, que era constituída por soldados poloneses e estava sob comando britânico, teve participação ativa em vários combates ocorridos na Normandia, na Bélgica e nos Países Baixos, antes de chegar à Alemanha e tomar o porto de Wilhelmshaven, na região da Baixa Saxônia. Sobre o assunto consultar McGilvray (2013). 
Vocês não imaginam como é que juntar tanta gente que ficou, sabe, nas fábricas, nos baurs, que baurs é fazendas, trabalhando, não se comunicando, de repente, veio o fim da guerra. Então, justamente veio os poloneses [...] a primeira divisão polonesa que estava com os aliados, então eles ajuntaram nós, sabe, tiraram os alemães das casas e colocaram nós... assim como os alemães faziam na Polônia... nas casas. Eu ... [por uma questão de] assim sabe, de consciência, eu pedi tanto para não tirar, tinha duas senhoras de idade numa casa meio grandinha, então eu pedi para deixar elas junto com nós, os poloneses e ucraínos e [lá] ficamos. (B. S. Kowalczuk, comunicação pessoal, 8 de junho, 2006)

Outro aspecto que chama atenção no fragmento acima é que, longe de manifestar qualquer ressentimento em relação aos seus inimigos, Bolka prefere assumir o papel de "salvadora", tal como ocorreu no episódio do recrutamento, ou seja, de alguém que tinha o dever de proteger toda e qualquer pessoa em situação de vulnerabilidade.

Todavia, após descrever o sentimento de euforia que tomou conta dos deslocados da Guerra nos dias que se seguiram à libertação, Bolka enfatiza que, com o fim do conflito, novos problemas precisaram ser enfrentados, pois além da falta de alimentos e de outros produtos básicos, o sistema de transporte e de comunicações também entrou em colapso.

Desse modo, o término da Guerra, não encerrou os dilemas pessoais de Bolka que, do mesmo modo que os mais de 10 milhões de deslocados, alimentava o sonho de voltar ao seu lugar de origem ou encontrar um local seguro para viver.

E [quando] terminou a guerra, a gente achava que podia voltar pra Polônia, mas a gente não sabia se tá alguém vivo. Se tá casa ainda no lugar, a gente não sabia nada, no mínimo quatro meses não tinha carta, não tinha nada. (B. S. Kowalczuk, comunicação pessoal, 8 de junho, 2006)

As recordações de Bolka sobre este período, marcado pela penúria e pela escassez, nos levam a refletir sobre a acertada observação de Portelli (2006, p. 69), de que a libertação, para além de uma experiência política, foi também uma experiência física e corporal. Ao falar sobre as suas condições de vida após a libertação, ela afirma que ficou durante cinco meses em uma fazenda, que após a chegada dos Aliados, provavelmente foi transformada em um campo de deslocados da Guerra. Sobre as condições de vida das pessoas que partilharam aquele espaço, ela relembra:

Como é que vocês podem imaginar a situação: colocam cinco meninas diferentes, completamente diferentes, sabe, de educação, de pensamento, sabe, num quarto. Claro que tendo pra cada uma, uma cama ... uma tá dormindo no sofá, a outra tá dormindo num pedaço de colchãozinho, sabe, porque tiraram os alemães e colocaram nós, sabe [...]. Os soldados cozinhavam no caldeirão e você não tinha como pegar [o alimento]. Você pega numa latinha, sabe... é tão difícil pra vocês entender que melhor nem pensem nisso, sabe [choro]. Não é fácil. Depois, sabe, você não tem parente, não tem ninguém você estava numa fazenda e você não conhecia em volta ninguém. Você não tem conhecimento de ninguém... de repente te empurram junto com outras pessoas. (B. S. Kowalczuk, comunicação pessoal, 8 de junho, 2006) 
Ao responder uma de nossas perguntas sobre a precariedade destes locais, ela destaca o auxílio que receberam da Cruz Vermelha:

A Cruz Vermelha, a Cruz Vermelha, meu Deus do céu, que coisa, maravilhosa [choro]. A Cruz Vermelha mandava esses pacotes, sabe, prá nós. Tinha lá tudo, sabe, um pedaço de chocolate, um pouco de chá, um pouco de café ... sabonete, puxa vida! Às vezes um sabão em pó, essas coisas assim, do que precisava. Uma coisa... margarina, sabe, puxa vida, às vezes a manteiga fica velha, feia, ruim, sabe, biscoitos ... Mas na hora de dividir esses pacotes ... essa divisão é uma coisa triste, porque esses que dividiam sempre tinham os seus preferidos e esses que não estavam preferidos ganhavam o resto do papel da margarina ou..., sabe. Vocês imaginem tudo isso. (B. S. Kowalczuk, comunicação pessoal, 8 de junho, 2006)

Foi nesse local que Bolka acabou conhecendo seu futuro marido, Waclaw Kowalczuk, filho de imigrantes poloneses, nascido no Brasil. Kowalczuk fazia parte de um grupo de aproximadamente 400 rapazes, composto de filhos ou netos de imigrantes poloneses, que no início da década de 1940 deixou o Brasil para se alistar como voluntário no exército polonês ${ }^{15}$.

Foi [no final de guerra] que eu conheci o meu marido [...]. Pegaram todos nós assim, sabe, e colocaram numa aldeia. E lá eu conheci o meu marido. Ele se alistou no exército polonês que se fundou lá na Inglaterra, mais na Escócia, sabe. E eles desembarcaram lá na França; e pela Bélgica, Holanda, justamente eles chegaram lá onde eu estava. E o destino quis que nós se conhecemos e casamos lá, sabe, na Alemanha. Claro, sem o conhecimento dos meus pais nem pais dele que moravam aqui no Brasil, né. (B. S. Kowalczuk, comunicação pessoal, 8 de junho, 2006)

A ausência de notícias sobre sua família, somada à falta de segurança para empreender a viagem de retorno e, por fim, o casamento com um descendente de poloneses, de nacionalidade estrangeira, foram fatores determinantes para que Bolka deixasse de retornar à Polônia, naquele momento.

Pelo fato de ter se casado com um indivíduo de nacionalidade brasileira, ela obteve o visto de imigrante para o Brasil, sem precisar recorrer a ajuda de organismos internacionais, que atuavam intensamente na realocação dos deslocados da Guerra. Mesmo assim, Bolka ainda permaneceu na Alemanha por mais dois anos ${ }^{16}$. Durante esse período, fez várias tentativas para se comunicar com seus genitores, mas não obteve nenhuma resposta. Somente após ter se radicado no Brasil, onde ela e o marido chegaram em setembro de $1947^{17}$, Bolka conse-

\footnotetext{
15 Sobre o assunto consultar Álvarez \& Kojrowicz (2020).

${ }^{16}$ Nesse período ela realizou um curso técnico de enfermagem, embora nunca tenha atuado profissionalmente.

17 A partir dessa data, Bolka passou a residir em Curitiba, capital do estado do Paraná, local onde a família do seu marido, estava radicada desde o final do século XIX.
} 
guiu, finalmente, restabelecer o contato com a família ${ }^{18}$. As primeiras notícias vindas da Polônia foram recebidas com muito alívio e alegria. Ao ler a carta, escrita pelo irmão, Bolka ficou sabendo que, apesar de todo o sofrimento causado pela Guerra ${ }^{19}$, os pais, felizmente, estavam vivos e com saúde. Obviamente, o principal assunto tratado nesta carta dizia respeito ao sentimento de felicidade que tomou conta da família quando os pais receberam notícias de Bolka e souberam que ela estava viva, depois de tantos anos de ausência.

Após este primeiro contato, Bolka passou a alimentar o sonho de um dia poder rever os pais. Todavia, as condições materiais e os afazeres como mãe, esposa e dona de casa não permitiam a realização de uma viagem de tamanho porte. Somente na década de 1970, quando seus quatro filhos já eram adultos e o marido, aposentado, surgiu a oportunidade de realizar a tão esperada viagem. O retorno à aldeia de Kędziorowo ocorreu em 1976, quando ela e o marido viajaram à Polônia e lá permaneceram por aproximadamente três meses. Em sua narrativa, o longo período que ficou afastada da família, bem como o incentivo da filha para que ela voltasse à Polônia mereceram destaque:

Olha, depois de 35 anos, vocês imaginem... Eu tenho uma filha, ela agora mora no Canadá... ela veio e disse assim... pegou eu como se fosse uma boneca de pano, sabe, e disse: 'Mãe eu quero que vocês vão para a Polônia, quero que você vá ver sua mãe'. (B. S. Kowalczuk, comunicação pessoal, 8 de junho, 2006)

A viagem à terra natal e sobretudo o reencontro com os pais e o irmão, após o largo intervalo de mais de três décadas, foram narrados por Bolka como se ela estivesse descrevendo um filme épico, no qual era preciso chamar a atenção dos expectadores para que eles pudessem acompanhar a sua narrativa, sem perder nenhum detalhe do roteiro. Ademais, como lembra Leonor Arfuch, "contar a história de uma vida é dar vida a essa história” (Arfuch, 2010, p. 42).

Mas olha, agora que eu vou falar para vocês, agora vocês vão ouvir. Então... chegamos. Puxa vida, de avião. Perto a gente já tá vendo que já vai aterrizar: Polônia, Varsóvia, meu Deus do céu. A gente parece que tem dentro [de si] um formigueiro, sabe. A gente pegou trem e vai lá, longe ainda, duzentos e poucos quilômetros de Varsóvia, lá no Norte. (B. S. Kowalczuk, comunicação pessoal, 8 de junho, 2006)

\footnotetext{
${ }^{18}$ De acordo com a narrativa da entrevistada, somente dois anos depois de sua chegada a Curitiba ela conseguiu, com a ajuda da Cruz Vermelha Brasileira, entrar em contato com o irmão. Segundo ela, em virtude da ausência de notícias após o término da guerra, a família considerava que ela estivesse morta.

${ }^{19}$ Além da morte da filha mais velha e da ausência de Bolka, a família Smolinska teve a casa completamente destruída durante um bombardeio.
} 
Como se estivesse sentindo novamente um formigueiro no interior de suas entranhas, ela friccionou as mãos e buscando traços armazenados na sua memória, reconstruiu a cena da chegada à casa de sua infância. Afinal, os sentimentos e as emoções que esse lugar despertava eram de pertença, de um lugar no mundo, com raízes profundas.

Nós chegamos lá [em Kędziorowo], sabe, eu já fui conhecendo: 'Mas esta casa já tá nova, essa tá nova, a minha também, já foi, sabe, bombardeada, sabe, modificada, mas no mesmo lugar, o mesmo estilo. Entramos, sabe, e portão não tava fechado, entramos lá perto do poço, sabe, e eu dizendo para mim: 'Olha Bolka, você tem que ser forte, tua mãe já tem 76 anos' [...] a tua mãe está com 76 anos, você não pode assustar [...]. (B. S. Kowalczuk, comunicação pessoal, 8 de junho, 2006)

Sem vacilar, num fluxo contínuo de palavras, ela deu continuidade à sua construção narrativa, relatando com a ajuda de gestos, o momento em que, finalmente, pode abraçar a sua mãe:

Ela tava assim de lenço assim amarrado atrás, branco [...] meu Deus do céu, eu achava que eu não ia aguentar, sabe, pegar ela com jeitinho, mas não dá, não adianta! Mas quando eu gritei: 'Mama! [...], ainda consegui pegar ela nos braços e ela quase desmaiou... (B. S. Kowalczuk, comunicação pessoal, 8 de junho, 2006)

Diante do seu silêncio em relação à figura do pai, foi perguntado se à época da visita à Polônia, ele ainda era vivo, e ela prontamente respondeu:

Tava vivo! Aí o meu sobrinho correu ligeiro, que meu pai estava na roça, sabe, arando. Ele deixou os cavalos, tirou a botina e acho que correu não sei quanto tempo, meu Deus do céu! O pai era bastante amoroso... (B. S. Kowalczuk, comunicação pessoal, 8 de junho, 2006)

Por fim, olhando pela janela, ela recuperou da grande massa de lembranças uma recordação preciosa e, a sorrir, narrou a cena em que seu pai anunciou a toda vizinhança da aldeia, a volta da filha.

Nós chegamos antes da festa de Páscoa [...]. Então, toda carroça que passava, ele dizia: 'Essa é minha filha que voltou'. E a gente dizia: 'Pai não fale, assim. Não, não'. E ele: 'Olha aí minha filha!' Ai meu Deus do céu, assim sabe [...]. Parecia esse tipo telefone sem fio, sabe, passou setenta e tantos números de casa, todo mundo já sabia que Bolka voltou. (B. S. Kowalczuk, comunicação pessoal, 8 de junho, 2006)

\section{À GUISA DE CONCLUSÃO}

No antológico texto escrito por Benjamin no período entre-guerras, no qual o filósofo berlinense problematiza a figura do narrador, encontra-se um alerta sobre o desparecimento da arte de narrar.

Segundo Benjamin, o surgimento do romance, no início do período moderno e a difusão da informação, teriam contribuído fortemente para o declínio 
da troca de experiência por parte dos narradores anônimos. Nessa perspectiva, enquanto o romancista e os profissionais da imprensa assumem a tarefa de decodificar aspectos da realidade, o único compromisso do narrador é compartilhar experiências, permitindo que seus interlocutores se apropriem livremente de elementos que mais lhe interessarem.

À primeira vista, ao ouvirmos a narrativa de Bolka, poderíamos concluir que se trata de uma história, com final feliz. Afinal, como em um conto de fadas, nossa protagonista conseguiu, depois de muitos percalços, retornar a sua casa de infância, a tempo de poder rever os pais e partilhar com eles algumas semanas de convívio.

Entretanto, se deixarmos de lado a "ilusão biográfica", apontada por Bourdieu como um dos equívocos cometidos por aqueles que enxergam a história de vida como uma sucessão ordenada de acontecimentos, que se desenrolam unicamente a partir da trajetória individual do sujeito, podemos analisar a narrativa autobiográfica de Bolka sob um outro ângulo. Ou seja, sua história de vida, longe de se configurar como o mero relato de alguém que enfrentou obstáculos e, no final, foi bem sucedido, se constitui como um instrumento de reconstrução identitária que traz à tona uma experiência repleta de sentidos. Experiência essa que ressurge a partir de narrativas envoltas por recordações traumáticas, algumas vezes situadas nas "fronteiras do dizível" e outras encobertas pelo véu do esquecimento.

Nesse sentido, temos ciência de que no esforço de integrar o presente ao passado, nossa entrevistada precisou fazer escolhas sobre aquilo que deveria ser dito, ordenando, destacando ou suprimindo acontecimentos e personagens que fizeram parte de sua experiência vivida. Como já ressaltou Artières (1998, p. 11), nas narrativas autobiográficas "não só escolhemos alguns acontecimentos, como os ordenamos numa narrativa", sempre no intuito de delinear o sentido que desejamos dar às nossas vidas.

Por fim, arriscamos dizer que, a disposição de Bolka em dividir conosco a sua história de vida, para além de enriquecer nossa experiência e trazer questões instigantes para a reflexão sobre memória e esquecimento, também teve repercussões na sua própria experiência como narradora.

Durante o trabalho de "gestão da identidade", inerente ao exercício de rememoração, ela selecionou acontecimentos que fizeram emergir sentimentos, mágoas e ressentimentos, aparentemente soterrados pela memória, que tornavam a sua "história difícil de ser contada". Todavia, ao encontrar uma escuta, ela pode, enfim, resgatar alguns fios, que mesmo esgarçados por recordações traumáticas, possibilitaram a tessitura de novas histórias. 


\section{REFERÊNCIAS}

Arfuch, L. (2010). O espaço biográfico: Dilemas da subjetividade contemporânea. Editora UERJ.

Artières, P. (1998). Arquivar a própria vida. Estudos Históricos, 11(21), 9-34.

Álvarez, F. P., \& Kojrowicz, C. S. (2020). Poloneses de Brasil y Argentina unidos en tiempos de guerra. Revista X, 15(6), 423-445. https://doi.org/10.5380/rvx.v15i6.76940

Benjamin, W. (1985). Teses sobre filosofia da história. In F. R. Kothe (ed.), Sociologia (pp. 153-164). Ática.

Benjamin, W. (1987). O narrador. Considerações sobre a obra de Nikolai Leskov (1936). In W. Benjamin (Ed.), Magia e técnica, arte e política: Ensaios sobre literatura e história da cultura (pp. 197-221). Brasiliense.

Calegari, L. C. (2019). Trauma, memória e testemunho em "A vida e a luta de uma sobrevivente do Holocausto", de Sabina Kustin. Literatura e Cinema de Resistência, (32). 87-98. https://doi.org/10.5902/1679849X35092

Candau, J. (2013). Antropologia da Memória. Instituto Piaget.

Coggiola, O. (2015). A Segunda Guerra Mundial: Causas, estrutura, consequências. Editora Livraria da Física.

Guillaumin, J. (1968). La genese du souvenir : Essai sur les fondements de la psychologie de l'enfant. Presses universitaires de France.

Holocaust Museum. (s.d.-a). Trabalho forçado: visão geral. Enciclopédia do Holocausto. https://encyclopedia.ushmm.org/content/pt-br/article/forced-labor-an-overview

Holocaust Museum. (s.d.-b). Vítimas polonesas. Enciclopédia do Holocausto. https://encyclopedia.ushmm.org/content/pt-br/article/polish-victims

Jelin, E. (2002). ¿De qué hablamos cuando hablamos de memorias? In E. Jelin (Ed.), Los trabajos de la memoria. https://laasociacion.files.wordpress.com/2015/11/memoria-jelc3adn-1.pdf

Loriga, S. (2009). A tarefa do historiador. In A. de C. Gomes \& B. B. Schmidt (Eds.), Memórias e narrativas (auto)biográficas (pp. 13-37). FGV; UFRGS.

Lowenthal, D. (1998). Como conhecemos o passado. Projeto História, (17), pp. 63-201.

Lukas, R. (1986). O Holocausto esquecido: Os poloneses sob ocupação alemã, 1939-1944. University Press of Kentucky.

McGilvray, E. (2005). Black Devils' March - a doomed odyssey: The 1st Polish Armoured Division 1939-1945. Helion and Company.

Milan, P. (2012, 15 de agosto). A vida em um campo de trabalho forçado. Gazeta do Povo. https://www.gazetadopovo.com.br/vida-e-cidadania/a-vida-em-um-campo-de-trabalhoforcado-2zl1mul4sqzejog7e88f22826/

Pollak, M. (1989). Memória, esquecimento, silêncio. Estudos Históricos, 2(3), 3-15.

Pollak, M. (1992). Memória e identidade social. Estudos Históricos, 5(10), 200-212.

Pollak, M. (2010). A Gestão do indizível. WebMosaica, 2(1), 9-49. 
Portelli, A. (2006). A Bomba de Turim: a formação da memória no pós-guerra. História Oral, 9(1), 69-89. https://doi.org/10.51880/ho.v9i1.190

Ricoeur, P. (1995). O perdão pode curar? http://www.lusosofia.net/textos/paul_ricoeur_o_perdao_pode_curar.pdf

Ricoeur, P. (1999). La lectura del tiempo pasado: Memoria y olvido. Arrecife.

de Salis, A. U. (2020). O silêncio do Leste: Refugiados do stalinismo no Paraná [Tese de doutorado, Pontifícia Universidade de São Paulo]. TEDE: Teses e Dissertações dos Programas de Pós-Graduação da PUC-SP. https://sapientia.pucsp.br/bitstream/handle/23238/2/Andr\%c3\%a9\%20Ulysses\%20De\%20Salis.pdf

Santo Agostinho. (2008). Confissões (A. do Espírito Santo, J. Beato \& M. C. Castro-Maia de Sousa Pimentel, trad.). Universidade da Beira Interior.

Santos, R. (2020). Em busca de um lar: práticas culturais e representações da família Egert na região de Guarapuava-PR (1949-2016) [Tese de doutorado, Universidade Estadual de Maringá]. Repositório Institucional da Universidade Estadual De Maringá (RI-UEM). http://repositorio.uem.br:8080/jspui/bitstream/1/6065/1/Rodrigo\%20dos\%20Santos_2020.pdf

Seligmann-Silva, M. (2005). Literatura e trauma: um novo paradigma. In M. Seligmann-Silva (Ed.), O local da cultura: Ensaios sobre memória, arte, literatura e tradução (pp. 63-80). Editora 34.

Shephard, B. (2012). A longa estrada para casa: Restabelecendo o cotidiano na Europa devastada pela guerra. Paz e Terra.

Varikas, E. (2014). A escória do mundo: Figuras do pária. Unesp. 
